This article has been accepted for publication in Antiquity. This version is free to view and download for private research and study only. Not for re-distribution, re-sale or use in derivative works. (C) Antiquity Publications Ltd, 2018

\title{
Rows with the neighbours: the short lives of longhouses at the Neolithic site of Versend-
}

\section{Gilencsa, Hungary}

János Jakucs ${ }^{1}$, Krisztián Oross ${ }^{1}$, Eszter Bánffy ${ }^{1,2}$, Vanda Voicsek ${ }^{3}$, Elaine Dunbar ${ }^{4}$, Paula Reimer $^{5}$, Alex Bayliss ${ }^{6,7}$, Peter Marshall ${ }^{6}$ \& Alasdair Whittle ${ }^{8 *}$

${ }^{1}$ Institute of Archaeology, Research Centre for the Humanities, Hungarian Academy of Sciences, Tóth Kálmán utca 4, 1097 Budapest, Hungary

${ }^{2}$ Römisch-Germanische Kommission, DAI, Palmengartenstraße 10-12, 60325 Frankfurt, Germany

${ }^{3}$ Barátúr utca 9, 7625 Pécs, Hungary

${ }^{4}$ SUERC Radiocarbon Dating Laboratory, Scottish Enterprise Technology Park, Rankine Avenue, East Kilbride G75 OQF, UK

${ }^{5}{ }^{14}$ CHRONO Centre, Queen's University Belfast, 42 Fitzwilliam Street, Belfast BT9 6AX, UK

${ }^{6}$ Historic England, Fourth Floor, Cannon Bridge House, 25 Dowgate Hill, London EC4R $2 Y A, U K$

${ }^{7}$ Biological and Environmental Sciences, University of Stirling, Stirling FK9 4LA, UK

${ }^{8}$ Department of Archaeology and Conservation, Cardiff University, John Percival Building, Colum Drive, Cardiff CF10 3EU, UK

* Author for correspondence (Email: whittle@cardiff.ac.uk)

Received: 11 November 2016; Accepted: 13 February 2017; Revised: 26 April 2017

<LOCATION MAP $6.5 \mathrm{~cm}$ colour, place to left of abstract and wrap text around>

Longhouses culture are a key feature of Neolithic Linearbandkeramik (LBK) settlements in central Europe, but debate persists concerning their usage, longevity, and social significance. Excavations at Versend-Gilencsa in southwest Hungary (c. 5200 cal BC) revealed clear rows of longhouses. New radiocarbon dates suggest that these houses experienced short lifespans. This paper produces a model for the chronology of Versend and considers the implications of these new dates for a fuller understanding of the layout and duration of LBK longhouse settlements. 
Keywords: Hungary; Versend-Gilencsa; Neolithic; LBK; longhouses; Bayesian chronological modelling

\section{Introduction}

Great timber longhouses are a defining feature of the first Neolithic communities in central and western Europe, belonging to the Linearbandkeramik (LBK) culture of the later sixth millennium cal BC (Coudart 1998). Even in the first recorded phase of longhouse construction (belonging to the LBK 'formative' phase), many elements of this architecture, such as longpits, side ditches and internal post rows, were already present (Bánffy 2013). During the succeeding (or earliest) LBK, buildings could be substantial, up to $20 \mathrm{~m}$ long or so by $6 \mathrm{~m}$ wide (Stäuble 2005). From the later LBK onwards, in the Flomborn, Ačkovy, Notenkopf and Keszthely phases, which began c. 5300 cal BC, some longhouses reach over $30 \mathrm{~m}$ in length and become more elaborate internally, the typical internal cross-rows of three posts changing to any number of combinations and layouts (Modderman 1970; Coudart 1998). Many settlements have been found, each characterised by larger and smaller groupings of long houses.

Despite their high archaeological visibility, wide distribution, and thousands of excavated examples, many questions remain about these iconic structures. Where did this architecture first emerge? In the virtual absence of preserved floors, what can be said about the use of the interiors? How long did these buildings last, given the substantial oak posts with which the majority of them were framed? How did houses relate to their neighbours? What did variation in house size mean in terms of household composition? Should each house be considered an independent unit, or was household membership distributed across more than one building?

Consideration of such questions was long framed by the Hofplatzmodell, or independent homestead model. This model emerged from pioneering, large-scale rescue excavations on the Aldenhovener Platte in north-western Germany (Boelicke et al. 1988), and is based on a complex set of arguments built upon a combination of site layouts, horizontal stratigraphy, ceramic sequence constructed through correspondence analysis of decorative motifs on fineware pottery, and an inferred house duration of some 25-30 years (summarised in Zimmermann 2012). The model posits that each longhouse existed in its own space-or yard in Dutch terminology (van de Velde 1979) — and is separated from irregularly spaced neighbours by a wider area that includes an activity zone spanning approximately $25 \mathrm{~m}$ (in the case of Langweiler 8: Boelicke et al. 1988). With each succeeding generation, these loose 
house clusters shifted slightly. Community thus comprised a combination of independent households, or groupings of such households, as seen at Vaihingen, south-western Germany, or Cuiry-lès-Chaudardes, northern France (Bogaard et al. 2011; Hachem 2011); wards are a useful term in this context (van de Velde 1979).

More recently, the Hofplatzmodell has been strongly criticised (Rück 2009, 2012). In its place, and principally on the basis of visual inspection of settlement plans, settlement layout based on rows of closely spaced longhouses aligned long side to long side has been proposed. Concurrently, differing hypothetical house durations up to and exceeding 75 years have been suggested (Schmidt et al. 2005: 162; Rück 2009). A wide range of candidates for row layout was suggested, essentially covering the LBK areas in central and western Europe. Other studies, particularly in the eastern part of this distribution, support the revision of the independent homestead model, without accepting all elements of the row model or necessarily following the proposed alternative estimated house duration (Lenneis 2012; Marton \& Oross 2012). Other variations, such as linked house pairs and other close-set clusters, have also been proposed (Czerniak 2016).

The chronology of neither the Hofplatzmodell nor its alternatives, however, has been formally modelled (although note Lenneis 2012). The site of Versend-Gilencsa in southwestern Hungary forms the focus of this paper. It provides an opportunity to jointly examine issues of layout and chronology, as it shows clear row layout and produced large assemblages of faunal remains suitable for radiocarbon dating.

\section{Longhouse architecture and settlement layout in western Hungary}

Archaeological research on LBK sites in western Hungary has intensified over the past two decades. By 2010 more than 300 houses from 50 sites were known (Oross 2013: 151-77, tab. 5.1, fig. 5.10, 401-402). The real number of excavated house plans is, however, much higher, as numerous discoveries remain unpublished. Their architecture is generally similar to contemporary houses in other regions of central Europe.

The excavated house plans from later sixth millennium cal BC settlements in western Hungary form clusters arranged into rows that are usually roughly parallel to each other. Each row consists of two to six houses with their long axes perpendicular to the row. Very similar settlement layout can be observed on large LBK sites of the region, with some rows located close to each other, as at Tolna-Mözs (Marton \& Oross 2012: 225-33, fig. 3). Elsewhere, as at Balatonszárszó-Kis-erdei-dűlő, there were some open spaces between the house rows (Oross 2013: 320-45). The nearby Szederkény-Kukorica-dülő settlement shares the same layout, 
although the house units were principally associated with early Vinča and Ražište style pottery (Jakucs et al. 2016).

\section{Versend-Gilencsa}

The large archaeological rescue excavation at Versend-Gilencsa (Figure 1) was carried out in 2006-2007 by archaeologists from the Janus Pannonius Museum, Pécs. The site lies in the area of the southern Baranya hills of Transdanubia, south of the village of Versend, and less than $3 \mathrm{~km}$ to the east of Szederkény-Kukorica-dülö (Jakucs et al. 2016). A 1.2km long strip, totalling over 6.5 ha, was excavated. The Neolithic settlement extends over low, gently sloping ridges (Figure 2), on both sides of the Versend stream.

$<$ FIGURE 1>

$<$ FIGURE 2>

In the eastern part of the Neolithic settlement, close to the stream, there were numerous traces of longhouses, oriented north-south. Although the postholes of these structures were poorly preserved, house plans could be identified from the characteristic longpits flanking the buildings. In this part of the site, at least 21 Neolithic house plans were identified, clearly arranged in at least four rows, nearly perpendicular to the streamline (Figure 2). Only one Neolithic burial was found here.

The western part of the site is more densely packed with features of different archaeological periods. Some were identified as potential Neolithic longpits due to their form. The locations of the suspected Neolithic houses are yet to be detected, due to later disturbance. This part of the settlement, however, yielded 24 burials which were mainly cut into larger pit complexes and appeared to form small clusters. Most of the burials were in a crouched position, but none had associated grave goods.

\section{Material culture}

A varied range of pottery styles was found at Versend, including Vinča, Ražište, early LBK and Starčevo (Figure 3). Starčevo was the first Neolithic cultural grouping in Transdanubia, dating to the first half of the sixth millennium cal BC. New evidence from Versend and other south-eastern Transdanubian sites has shown that inherited elements of the Starčevo pottery style could have been preserved to a greater extent than previously presumed (Marton \& Oross 2012). Vinča is the major post-Starčevo cultural grouping to the south of the LBK, the earliest manifestations of which date to the late fifty-fourth century cal BC (Whittle et al. 2016: fig. 25). The Ražište style, an early variant of the north-eastern Croatian Sopot culture 
(on the fringes of the early Vinča culture), may have resulted from interaction between the Vinča and LBK spheres (Marković 2012; Jakucs \& Voicsek 2015). Additionally, decorative elements of the Malo Korenovo type (a regional variant of the LBK in northern Croatia and south-western Hungary; Težak-Gregl 1993) also occur.

\section{<FIGURE 3>}

Early Vinča-style ceramics, figurines and bone tools are the dominant artefacts found in the buildings of the northern house row of the eastern settlement area, especially in houses H15 and H17 (Figure 4). In most houses, however, early Vinča-style vessel forms and technological markers occur together with early LBK-style ceramics (and in the cases of H3, H5, H7 and H15, with figurines as well), and also in some cases with material that appears to hark back to the Starčevo tradition (H10, H11 and H12). Analyses to date suggest relatively strong Vinča influences in the material culture of some houses in the eastern area of Versend, whereas other houses in the eastern area show stronger affiliations to the rest of Transdanubia (Figures 3-4). Ongoing post-excavation analysis has provided a different picture for the western side of the settlement. Although distinctive early Vinča elements, such as black burnishing, black-topped vessels and red slipping are numerous, there were significant differences in vessel forms and decorative techniques. The vessel forms and applied decorative patterns are most analogous to the Sopot-Ražište style ceramics of eastern Slavonia. Additionally, decorative elements of the Malo Korenovo pottery style are more frequent in this part of the site.

$<$ FIGURE 4>

\section{Radiocarbon dating}

The radiocarbon dating programme for Versend was designed using Bayesian chronological modelling (Buck et al. 1996), incorporating the four radiocarbon dates on human skeletons that had been obtained previously (MAMS-; Table 1). The sampling strategy aimed to date the occurrence of longhouses and Vinča ceramics on the same site, to explore the layout of the eastern part of the settlement, and to determine whether occupation at Versend was contemporary with that at nearby Szederkény-Kukorica-dülö.

\section{$<$ TABLE 1>}

Sampling was concentrated on the eastern part of the settlement where the layout of the buildings could be reconstructed. A small number of samples were dated from the western area to check that both areas were occupied simultaneously. The entire faunal assemblage from the eastern part of the site was assessed for groups of articulating bones and bones with 
re-fitting unfused epiphyses (cf. Bayliss et al. 2016: fig. 7). This material must have been rapidly deposited after death for the elements to remain articulated. Strictly, such samples provide a terminus ante quem for the construction of each longhouse. It is likely, however, that the chronological difference between the deposition of the dated animal bones and house construction is relatively small as none of the recovered material came from the upper parts of features (the top $0.4 \mathrm{~m}$ was mechanically removed prior to excavation).

Sixty-eight radiocarbon measurements are available from Versend, all on samples of articulating animal or human bone (Table 1). Technical details of the results and the methods used to produce them are provided in the online Supplementary Material.

\section{Modelling the chronology of the Neolithic settlement at Versend-Gilencsa}

Chronological modelling was undertaken using OxCal v4.2 (Bronk Ramsey 2009a; Bronk Ramsey \& Lee 2013) and the calibration dataset of Reimer et al. (2013) (the model algorithms are defined exactly by the OxCal CQL2 code provided in online supplementary materials). The structure of the preferred model (Model 4) is illustrated by the brackets and OxCal keywords on the left-hand side of Figures 5 and 6 (http://c14.arch.ox.ac.uk/). The outputs from the models, the posterior density estimates, are shown in black, and the unconstrained calibrated radiocarbon dates are shown in outline. The other distributions correspond to aspects of the model. For example, the distribution start Versend settlement (Figure 5) is the posterior density estimate for the time when the settlement at Versend was established. In the text and tables, the Highest Posterior Density intervals of the posterior density estimates are given in italics.

\section{<FIGURE 5>}

$<$ FIGURE 6>

A number of alternative models for understanding the chronology of Versend have been constructed. They all include the limited number of stratigraphic relationships between dated features (Grave 415 is earlier than Pit 414 of H18, Pit 1123 is earlier than Graves 1121 and 1124, and Pit 1387 is earlier than Grave 1394). Replicate radiocarbon measurements are combined by taking a weighted mean (Ward \& Wilson 1978) before calibration and inclusion in the models, and the three measurements on intrusive samples of post-Neolithic date are excluded.

Model 1 (Versend_Model_1.oxcal) includes all of the settlement features and burials in a single, continuous uniform phase of activity (Buck et al. 1992). It has poor overall agreement (Amodel: 46; Bronk Ramsey 2009a, 356-7), with burials 1049 (SUERC-67305) 
and 1078 (SUERC-67306) clearly continuing later than the dated settlement. Model 2 (Versend_Model_2.oxcal), therefore, places the settlement features and the burials in separate, potentially overlapping, continuous uniform phases of activity (cf. the model structures illustrated in Figures 5 and 6). This model has poor overall agreement (Amodel: 56) and poor overall convergence $(\mathrm{C}: 85)$, with three samples having poor individual agreement (Bronk Ramsey 1995, 429; UBA-22596, A: 42; UBA-22602, A: 46, and SUERC-58578, A: 1). A variant of this, Model 3 (Versend_Model_3.oxcal), which splits the settlement into its eastern and western parts, has good overall agreement (Amodel: 63) but poor overall convergence (C: 83), with the same three measurements having poor individual agreement (A: 44; A: 47, and A: 4 respectively). SUERC-58578 is statistically significantly earlier than the other measurements on similar samples from the longpits of $\mathrm{H} 15\left(\left(\mathrm{~T}^{\prime}=20.4 ; \mathrm{T}^{\prime}(5 \%)=11.1\right.\right.$; $v=1$; Ward \& Wilson 1978)), and indeed is clearly earlier than all the other dated samples from the site (see Figure S1). Given its articulation, it appears unlikely to be residual from an earlier feature and so is likely to be a laboratory outlier.

Model 4 (Versend_Model_4.oxcal), therefore, implements outlier analysis to identify and proportionally weight any statistical outliers arising from unquantified laboratory error in the data ((Outlier_Model("SSimple",N(0,2),0,"s"); Christen 1994; Bronk Ramsey 2009b). This model is identical in form to Model 2, but implements s-type outlier analysis in OxCal, with each radiocarbon measurement being given a prior outlier probability of $5 \%$. Only SUERC-58578 (83\%) and UBA-22602 (11\%) have posterior outlier probabilities of more than $10 \%$, and it is again clear that SUERC-58578 is a significant outlier from the main body of data from the settlement (the outlier analysis downweights this date proportionately). Model 4 is defined by the CQL2 code provided as supplementary information (Versend_Model_4.oxcal), although its overall form is illustrated in Figures 5 and 6. The first and last dated events have been calculated for each longhouse that has yielded more than two radiocarbon dates. The difference between them provides an estimate for the duration of use of each building, bearing in mind that the upper longpit fills are probably missing. These key parameters are illustrated in Figures 7 and 8, and their Highest Posterior Density intervals are given in Table 2.

$<$ FIGURE 7>

<FIGURE 8>

$\langle$ TABLE 2>

Obtaining a statistically plausible and stable model for the chronology of Versend has been challenging, due to the shape of the radiocarbon calibration curve between $c .5300$ and $c$. 
5000 BC (Figure S1). This consists of two small plateaux separated by a pronounced wiggle, which leads to strongly bi-modal posterior distributions. Consequently, the models are extremely slow to converge or are unable to achieve adequate convergence at all (Bronk Ramsey 1995, 429). The highest peaks of probability in all of our variant models, however, suggest a short-lived settlement occupied for a few decades around $5200 \mathrm{cal} \mathrm{BC}$. As this coincides with a steep part of the calibration curve separating two small plateaux, we were concerned that our results could be an artefact of the shape of the curve. For this reason, we ran 14 simulation models identical in form to Model 1, each spanning 30 years and starting from $5270 \mathrm{BC}$ to $5130 \mathrm{BC}$. The posterior distributions produced by these simulations included the actual dates in accordance with statistical expectation (Table S1), and so we feel that the model outputs presented should be accurate to within the quoted uncertainty.

The model shown in Figure 5 suggests that the Versend settlement was established in 5305-5280 cal BC (2\% probability; start Versend settlement; Figure 5) or 5255-5210 cal BC (93\% probability), probably in 5235-5215 cal BC (68\% probability), and was abandoned in 5220-5180 cal BC (93\% probability; end Versend settlement; Figure 5) or 5150-5115 cal BC (2\% probability), probably in $5210-5195$ cal BC (68\% probability). It was in use for $1-70$ years (93\% probability; use Versend settlement; Figure 8 ) or $135-185$ years (2\% probability), probably for 10-35 years ( $68 \%$ probability). Given the short overall duration of the settlement, most houses were probably in use for no more than a decade or two (Figure 8). Burial occurred for longer on the site, beginning in 5395-5225 cal BC (95\% probability; start Versend burials; Figure 6), probably in 5330-5240 cal BC (68\% probability) and ending in 5040-4815 cal BC (95\% probability; end Versend burials; Figure 6), probably in 4995-4905 cal BC (68\% probability). It continued for a period of $215-540$ years (95\% probability; use Versend burials; distribution not shown), probably for a period for 275-415 years (68\% probability). This persistence in burial is in stark contrast to the brevity of settlement on the site.

\section{Discussion}

Model 4 suggests not only short durations for individual longhouses in Versend-Gilencsa (median values not exceeding 20 years; Figure 8), but also, in complementary fashion, a short life for the settlement as a whole, in the late fifty-third century cal BC. Although fewer in number, dates from the western part indicate a similar period of use to the eastern part. The longer duration for burial on the site, although unusual in this type of context, does not conflict with the modelled brevity of settlement. In assessing the implications of these 
formally modelled estimates, we must restate the nature of our dated samples. Our short-life samples came principally from pits flanking the longhouses in the eastern part of the settlement, and it is believed that those features were truncated. Furthermore, it is not entirely clear how the filling of these pits relates to the lifespan of individual buildings. Did these features fill up quickly? Were the finds in them foundation deposits? Were they recut periodically? These are questions that apply across the whole LBK distribution (cf. Stäuble 1997), and are therefore open to testing in other cases. Our proxy, however, is the best available for Versend-Gilencsa, and is likely to be the kind of proxy found in many other LBK contexts.

The estimated short house durations, therefore, have not only local significance (discussed below), but also potential wider implications for the debate concerning the forms and timings of LBK settlements. The eastern part of Versend-Gilencsa is unequivocally arranged in rows, as is probably the western part. This example, and plenty of others in Transdanubia and east-central Europe, therefore confirm the spatial dimension of the row model (Rück 2009, 2012). Our date estimates for house longevity, however, conform well to the estimates produced by the Hofplatzmodell (Zimmermann 2012), and are considerably shorter than those proposed as a corollary of the row model. It remains to be seen, of course, whether similar results can be produced by formal modelling of other LBK longhouse settlements. The few other formally modelled estimates for house duration in other Neolithic contexts available generally support shorter rather than longer house lives. In the tell settlements of Vinča-Belo Brdo, Serbia, and Uivar, Romania, for example, median house durations range from 4-55 years and from 11-82 years respectively (Tasić et al. 2016: fig. 10; n=10; Draşovean et al. 2017: fig. 7; n=8); many houses appear to have lasted from one to two human generations. All such estimates have to be contextualised.

We have suggested that some houses in the early stages of tell development could have been deliberately abandoned to create memory and renown (Draşovean et al. 2017), and that house life in the late stages of Vinča-Belo Brdo tell could have been shortened by circumstances of very unsettled times (Tasić et al. 2015). Precise dendrochronological dating suggests that short house lives ( $<20$ years) were also the norm in the Alpine foreland (Hofmann et al. 2016). Although variation is possible, it appears probable that Neolithic housing was rarely long-lived, even when solidly constructed. If such estimates are robust, we need to consider the reasons why. That involves thinking not only about the individual house and household but also the nature of communities and the specific circumstances in which they found themselves. 
There seems no reason why, with adequate maintenance (especially of the roof), LBK longhouses could not have been long-lasting. Their shorter lives, if that is what they normally had, must therefore be due to the social context in which they were built and used. People may have relocated buildings (and indeed whole settlements) for a number of practical reasons, including escape from infestation and unsanitary conditions (Whittle 1997). There are also well documented ethnographic cases where the death of household heads, and the associated pollution, are sufficient motive to abandon particular buildings. A well-known counter-example is the Zafamaniry house in Madagascar, which can endure in parallel with long-lasting marriage (Bloch 1995).

There is no specific evidence from individual houses at Versend-Gilencsa, and rarely elsewhere, that enables us to identify such influences. We must, however, consider flexibility and fluidity in household composition and durability, the wider context of groups of houses, and the circumstances in which they were built and used. The closely set rows at VersendGilencsa surely project a strong sense of community. Evidence suggests that the rows were relatively fully populated at the same time; only a few relationships (for example, H19 and 20; H14 and 16; Figure 2) suggest successive building. Setting out rows of houses in the manner seen at Versend-Gilencsa - facing each other across narrow lanes and with their long sides very close to neighbours - was surely a deliberate act of community construction. Earlier settlement history in the region lends further support to this claim, when many occupations of both the Starčevo and Körös cultures might have had a less concentrated character (Bánffy et al. 2010). By analogy, whatever the situation may be with individual houses and households, it is likely that community was often fragile and divided; in settling in the same place, people probably had to work hard to stay together (Cohen 1985; Canuto \& Yaeger 2000; Amit 2002; Birch 2013: 8). In the American Southwest, early Mesa Verde villages have been called 'social tinderboxes', which rarely lasted beyond 30-70 years (Wilshusen \& Potter 2010: 178).

While individual house lives in tell settlements may have often been relatively short, occupation of place was maintained for centuries (Tasić et al. 2015, 2016; Draşovean et al. 2017). There is good reason to assume that many 'flat' settlements, including plenty of LBK examples, lasted for considerable periods of time. Formal modelling suggests, for example, that the occupation of nearby Szederkény-Kukorica-dülö lasted from the late fifty-fourth to the early fifty-second centuries cal BC (Jakucs et al. 2016); Tolna-Mözs, approximately 50km to the north along the Danube (Marton \& Oross 2012), provides another useful comparison. Szederkény, which combines the characteristically LBK longhouses with early Vinča style 
pottery, was probably founded soon after the initial LBK 'diaspora' across central Europe and beyond (Jakucs et al. 2016: fig. 24), and in circumstances of considerable social, cultural and demographic flux. This situation seems to have continued into the fifty-third century cal $\mathrm{BC}$, considering the range of ceramic styles seen at Versend-Gilencsa.

We must allow for the possibility that some villages ended much more quickly than others. In some cases, this may have been due to internal tensions, shifting alliances or external aggression. To date, there is no direct evidence from Versend-Gilencsa that allows us to identify specific factors, although the ceramic variability at the site could suggest the copresence of social groups with diverse cultural backgrounds and allegiances; this mix might have produced difficulties in maintaining community. In assessing the relevance of the modelled estimates presented here for longhouses and site duration, the possibilities of premature ending or social failure, in contingent circumstances, must be kept in mind. It remains to be seen whether other row settlements will yield similar results. If rows at one level were all about communal solidarity, it could be that households within them were also more prone to tension and fission, and therefore had shorter lives than the more independent and autonomous social units implied in the Hofplatzmodell.

\section{Acknowledgements}

Thanks to Boldizsár Csornay and Erzsébet Nagy for supporting our work in the Janus Pannonius Museum of Pécs; the Deutsche Forschungsgemeinschaft for funding the Bevölkerungsgeschichte des Karpatenbeckens in der Jungsteinzeit und ihr Einfluss auf die Besiedlung Mitteleuropas project, led by Kurt W. Alt and Eszter Bánffy; Kitti Köhler for her help with human bone identification; Éva Ágnes Nyerges and Hayley Foster for animal bone identification; and Zsolt Réti and Kirsty Harding for help with the figures. Dating and modelling were supported by an Advanced Investigator Grant (295412) of the European Research Council, for The Times of Their Lives (www.totl.eu), led by Alasdair Whittle and Alex Bayliss.

\section{Supplementary material}

To view supplementary material for this article, please visit XXXX

\section{References}

AMIT, V. 2002. Reconceptualizing community, in V. Amit (ed.), Realizing community: concepts, social relationships and sentiments: 1-20. London: Routledge. 
BÁNFFY, E. 2013. Tracing the beginning of sedentary life in the Carpathian basin, in D. Hofmann \& J. Smyth (ed.), Tracking the Neolithic house in Europe: sedentism, architecture, and practice: $117-49$. New York: Springer.

BÁNFFY, E., MARTON, T. \& OsZTÁs, A. 2010. Early Neolithic settlement and burials at Alsónyék-Bátaszék, in J.K. Kozłowski \& P. Raczky (ed.), Neolithization of the Carpathian Basin: northernmost distribution of the Starčevo/Körös culture: 37-51. Kraków and Budapest: Polish Academy of Arts and Sciences, and Institute of Archaeological Sciences of the Eötvös Loránd University.

Bayliss, A., Beavan, N., Hamilton, D., KÖHLer, K., Nyerges, É.Á., Bronk Ramsey, C., Dunbar, E., Fecher, M., Goslar, T., Kromer, B., Reimer, P., BÁnfFy, E., Marton, T., Oross, K., OszTÁs, A., Zalai-GaÁl, I. \& Whittle, A. 2016. Peopling the past: creating a site biography in the Hungarian Neolithic. Bericht der Römisch-Germanischen Kommission 94: 23-91.

BIRCH, J. 2013. Between villages and cities: settlement aggregation in cross-cultural perspective, in J. Birch (ed.), From prehistoric villages to cities: settlement aggregation and community transformation: 1-22. New York: Routledge.

BLOCH, M. 1995. The resurrection of the house amongst the Zafamaniry of Madagascar. In J.

Carsten \& S. Hugh-Jones (ed.), About the house: Lévi-Strauss and beyond: 69-83.

Cambridge: Cambridge University Press.

Boelicke, U., von Brandt, D., Lüning, J., Stehli, P. \& Zimmermann, A. 1988. Der bandkeramische Siedlungsplatz Langweiler 8. Gemeinde Aldenhoven, Kreis Düren. Köln: Rheinland-Verlag GmbH.

BogaArd, A., Krause, R. \& Strien, H.-C. 2011. Towards a social geography of cultivation and plant use in an early farming community: Vaihingen an der Enz, south-west Germany. Antiquity 85: 395-416.

BRONK RAMSEY, C. 1995. Radiocarbon calibration and analysis of stratigraphy. Radiocarbon 36: 425-30.

- 2009a. Bayesian analysis of radiocarbon dates. Radiocarbon 51: 337-60.

$-2009 b$. Dealing with outliers and offsets in radiocarbon dating. Radiocarbon 51: 1023-45.

BRONK RAMSEY, C. \& LEE, S. 2013. Recent and planned developments of the program OxCal. Radiocarbon 55: 720-30.

Buck, C.E., LITTON, C.D. \& SMITH, A.F.M. 1992. Calibration of radiocarbon results pertaining to related archaeological events. Journal of Archaeological Science 19: 497-512. 
BuCK, C.E., CAVANAGH, W.G. \& LiTTON, C.D. 1996. Bayesian approach to interpreting archaeological data. Chichester: John Wiley and Sons.

CANuto M.-A. \& YAEGER J. (ed.) 2000. The archaeology of communities: a New World perspective. London: Routledge.

CHRISTEN, J.A. 1994. Summarizing a set of radiocarbon determinations: a robust approach. Applied Statistics 43: 489-503.

CoHEN, A.P. 1985. The symbolic construction of community. Chichester: Ellis Horwood. COUdART, A. 1998. Architecture et société néolithique. L'unité et la variance de la maison danubienne. Paris: Maison des Sciences de l'Homme.

CZERNIAK, L. 2016. House and household in the LBK, in L. Amkreutz, F. Haack, D.

Hofmann \& I. van Wijk (ed.), Something out of the ordinary: interpreting diversity in the Early Neolithic Linearbandkeramik and beyond: 33-64. Newcastle upon Tyne: Cambridge Scholars Publishing.

Draşovean, F., Schier, W., Bayliss, A., Gaydarska, B. \& Whittle, A. 2017. The lives of houses: duration, context and history at Neolithic Uivar. European Journal of Archaeology. http://dx.doi.org/10.1017/eaa.2017.37

HACHEM, L. 2011. Le site néolithique de Cuiry-lès-Chaudardes, 1. De l'analyse de la faune à la structuration sociale. Rahden: Marie Leidorf.

Hofmann, D., Ebersbach, R., Doppler, T. \& Whittle, A. 2016. The life and times of the house: multi-scalar perspectives on settlement from the Neolithic of the northern Alpine foreland. European Journal of Archaeology 19, 596-630.

Jakucs, J., BÁnfFy, E., Oross, K., Voicsek, V., Bronk RAMSey, C., Dunbar, E., Kromer, B., Bayliss, A., Hofmann, D., Marshall, P. \& Whittle, A. 2016. Between the Vinča and Linearbandkeramik worlds: the diversity of practices and identities in the 54th-53rd centuries cal BC in south-west Hungary and beyond. Journal of World Prehistory 29: 267-336.

LENNEIS, E. 2012. Zur Anwendbarkeit des rheinischen Hofplatzmodells im östlichen Mitteleuropa, in F. Kreienbrink, M. Cladders, H. Stäuble, T. Tischendorf, \& S. Wolfram (ed.), Siedlungsstruktur und Kulturwandel in der Bandkeramik, 47-52. Dresden: Landesamt für Archäologie, Freistaat Sachsen.

MARKOVIĆ, Z. 2012. Novija razmatranja o nekim aspektima sopotske kulture u sjevernoj Hrvatskoj - Neuere Betrachtungen über bestimmte Aspekte der Sopot-Kultur in Nordkroatien. Priloži Instituta za Arheologija u Zagrebu 29: 57-70.

MARTON, T. \& OROSS, K. 2012. Siedlungsforschung in linienbandkeramischen Fundorten in Zentral- und Südtransdanubien — Wiege, Peripherie oder beides? in F. Kreienbrink, M. 
Cladders, H. Stäuble, T. Tischendorf \& S. Wolfram (ed.), Siedlungsstruktur und Kulturwandel in der Bandkeramik: 220-39. Dresden: Landesamt für Archäologie, Freistaat Sachsen.

ModDERMAN, P.J.R. 1970. Linearbandkeramik aus Elsloo und Stein. Analecta Praehistorica Leidensia 3.

OROSS, K. 2013. Balatonszárszó-Kis-erdei-dülö lelöhely középsö neolit településszerkezete és közép-európai párhuzamai. (The Middle Neolithic settlement structure of the site at Balatonszárszó-Kis-erdei-dülö in a Central European context). Budapest: PhD dissertation, Eötvös Loránd University.

Reimer, P.J., BARd, E., BAyliss, A., Beck, J.W., Blackwell, P., Bronk RAMSEy, C., Buck, C.E., Cheng, H., Edwards, R.L., Friedrich, M., Grootes, P.M., Guilderson, T.P., Haflidason, H., Hajdas, I., Hatté, C., Heaton, T.J., Hoffmann, D.L., HogG, A.G., Hughen, K.A., Kaiser, K.F., Kromer, B., Manning, S.W., Niu, M., Reimer, R.W., Richards, D.A., SCOTt, E.M., SOUTHOn, J.R., StAFF, R.A., TuRnEy, C.S.M. \& VAN DER PLICHT, J. 2013. IntCal13 and Marine13 radiocarbon age calibration curves 0-50,000 years cal BP. Radiocarbon 55: 1869-87.

RÜCK, O. 2009. New aspects and models for Bandkeramik settlement research, in D. Hofmann and P. Bickle (ed.), Creating communities: new advances in Central European Neolithic research: 159-85. Oxford: Oxbow Books.

- 2012. Vom Hofplatz zur Häuserzeile. Das bandkeramische Dorf - Zeilenstrukturen und befundfreie Bereiche offenbaren ein neues Bild der Siedlungsstrukturen, in F. Kreienbrink, M. Cladders, H. Stäuble, T. Tischendorf \& S. Wolfram (ed.), Siedlungsstruktur und Kulturwandel in der Bandkeramik: 20-42. Dresden: Landesamt für Archäologie, Freistaat Sachsen.

SCHMidT, B., GruHLE, W., RÜCK, O. \& FreCKMANN, K. 2005. Zur Dauerhaftigkeit bandkeramischer Häuser im Rheinland (5300-4950 v. Chr.) - eine Interpretation dendrochronologischer und bauhistorischer Befunde, in D. Gronenborn (ed.), Klimaveränderung und Kulturwandel in neolithischen Gesellschaften Mitteleuropas, 67002200 v. Chr.: 151-70. Mainz: Römisch-Germanisches Zentralmuseum.

STÄUBLE, H. 1997. Häuser, Gruben und Fundverteilung, in J. Lüning (ed.), Ein Siedlungsplatz der Ältesten Bandkeramik in Bruchenbrücken, Stadt Friedberg/Hessen: 17-150. Bonn: Habelt. - 2005. Häuser und absolute Datierung der Ältesten Bandkeramik. Bonn: Habelt. 
Tasić, N., Marić, M., Filipović, D., Penezić, K., Dunbar, E., Reimer, P., Barclay, A., BAYLISS, A., GAYDARSKA, B. \& WhitTLE, A. 2016. Interwoven strands for refining the chronology of the Neolithic tell of Vinča-Belo Brdo, Serbia. Radiocarbon 58(4). Doi: 10.1017/RDC.2016.56, Published online: 30 August 2016 Tasić, N., Marić, M., Penezić, K., Filipović, D., Borojević, K., Borić, D., Reimer, P., Russell, N., BAyliss, A., Barclay, A., Gaydarska, B. \& Whittle, A. 2015. The end of the affair: formal chronological modelling for the top of the Neolithic tell of Vinča-Belo Brdo. Antiquity 89: 1064-82.

TEŽAK-GREGL, T. 1993. Kultúra linernotrakaste keramike u sredisnjoj Hrvatskoj. Korenovska kultúra (The Linear Pottery culture in central Croatia. The Korenovo culture). Zagreb:

Dissertationes et Monographia 2.

VAN DE VELDE, P. 1979. On Bandkeramik social structure. Analecta Praehistorica Leidensia 12: $1-242$.

WARD, G.K. \& WILSON, S.R. 1978. Procedures for comparing and combining radiocarbon age determinations: a critique. Archaeometry 20: 19-31.

WhitTLE, A. 1997. Moving on and moving around: modelling Neolithic settlement mobility. In P. Topping (ed.), Neolithic landscapes: 15-22. Oxford: Oxbow Books.

Whittle, A., BAyliss, A., Barclay, A., Gaydarska, B., BÁNFFy, E., Borić, D., Draşovean, F., Jakucs, J., Marić, M., ORTON, D., TAsić, N., Schier, W. \& VANDER LINDEN, M. 2016. A Vinča potscape: formal chronological models for Neolithic cultural development in south-east Europe. Documenta Praehistorica 43, 1-60.

WiLshusen, R.H. \& PotTER, J.M. 2010. The emergence of villages in the American Southwest: cultural issues and historical perspectives, in M.S. Bandy \& J.R. Fox (ed.), Becoming villagers: comparing early village societies: 165-83. Tucson: University of Arizona Press.

ZimmermanN, A. 2012. Das Hofplatzmodell — Entwicklung, Probleme, Perspektiven, in F. Kreienbrink, M. Cladders, H. Stäuble, T. Tischendorf \& S. Wolfram (ed.), Siedlungsstruktur und Kulturwandel in der Bandkeramik: 11-19. Dresden: Landesamt für Archäologie, Freistaat Sachsen.

\section{Figure captions}

Figure 1. Map showing the location of principal sites mentioned in the text.

Figure 2. Layout of the eastern part of the Versend settlement, with at least four rows of longhouses clearly visible. 
Figure 3. The range of pottery styles and other material recovered from the eastern part of Versend: A) Starčevo; B) early $L B K$; C) Vinča.

Figure 4. The proportions of different pottery styles by row and longhouse in the eastern part of Versend.

Figure 5. Probability distributions of dates from the settlement at Versend; each distribution represents the relative probability than an event occurs at a particular time. Posterior/prior outlier probabilities are shown in square brackets. The structure of the model is shown by the brackets and OxCal keywords down the left-hand side of Figures 5 and 6. The model is defined exactly by the OxCal code provided as supplementary information (Versend_Model_4.oxcal).

Figure 6. Probability distribution of dates from burials at Versend. Format as for Figure 5. The structure of the model is shown by the brackets and OxCal keywords down the left-hand side of Figures 5 and 6. The model is defined exactly by the OxCal code provided as supplementary information(Versend_Model_4.oxcal).

Figure 7. Key parameters for the first and last dated events for houses with more than one radiocarbon date and for the establishment and abandonment of the settlement, derived from Model 4(Versend_Model_4.oxcal).

Figure 8. Key parameters for duration of houses with more than one radiocarbon date and the overall settlement, derived from Model 4(Versend_Model_4.oxcal). 
Table 1. Radiocarbon and stable isotopic measurements from Versend-Gilencsa. Replicate measurements have been tested for statistical consistency and combined by taking a weighted mean before calibration as described by Ward and Wilson $\left(1978 ; T^{\prime}(5 \%)=3.8, v=1\right.$ for

all).

\begin{tabular}{|c|c|c|c|c|c|c|}
\hline $\begin{array}{l}\text { Laboratory } \\
\text { number }\end{array}$ & Material, context, and associations & $\begin{array}{c}\delta^{13} C_{\text {IRMS }} \\
(\% \%)\end{array}$ & $\begin{array}{c}\delta^{13} \mathrm{C}_{\mathrm{AMS}} \\
(\% \%)\end{array}$ & $\delta^{15} \mathbf{N}(\%)$ & $\begin{array}{l}\mathrm{C} / \mathrm{N} \\
\text { ratio }\end{array}$ & $\begin{array}{l}\text { Radiocarbon } \\
\text { age (BP) }\end{array}$ \\
\hline \multicolumn{7}{|l|}{ Eastern } \\
\hline UBA-22601 & Pit 114 S2: replicate of SUERC-58556 & $-20.3 \pm 0.22$ & & $8.8 \pm 0.15$ & 3.2 & $6276 \pm 42$ \\
\hline \multicolumn{7}{|c|}{${ }^{14} \mathrm{C}: 6271 \pm 27 \mathrm{BP}, \mathrm{T}^{\prime}=0.0 ; \delta^{13} \mathrm{C}:-20.3 \pm 0.15 \%, \mathrm{~T}^{\prime}=0.1 ; \delta^{15} \mathrm{~N}: 8.8 \pm 0.13 \%$, $\mathrm{T}^{\prime}=0.1$} \\
\hline SUERC-58557 & $\begin{array}{l}\text { Pit } 114 \text { S3: cattle right distal humerus with refitting unfused epiphysis, } \\
\text { from the same feature as SUERC-67296 }\end{array}$ & $-19.5 \pm 0.2$ & & $8.1 \pm 0.3$ & 3.3 & $6185 \pm 34$ \\
\hline SUERC-58558 & $\begin{array}{l}\text { Pit } 128 \text { S2: articulating cattle left distal humerus and proximal radius, } \\
\text { from the same feature as UBA- } 22602\end{array}$ & $-19.8 \pm 0.2$ & & $5.7 \pm 0.3$ & 3.2 & $6306 \pm 32$ \\
\hline SUERC-67285 & Pit 128 S3: articulating cattle left astragalus and navicular cuboid, from & $-20.3 \pm 0.2$ & & $8.6 \pm 0.3$ & 3.3 & $6171 \pm 30$ \\
\hline
\end{tabular}




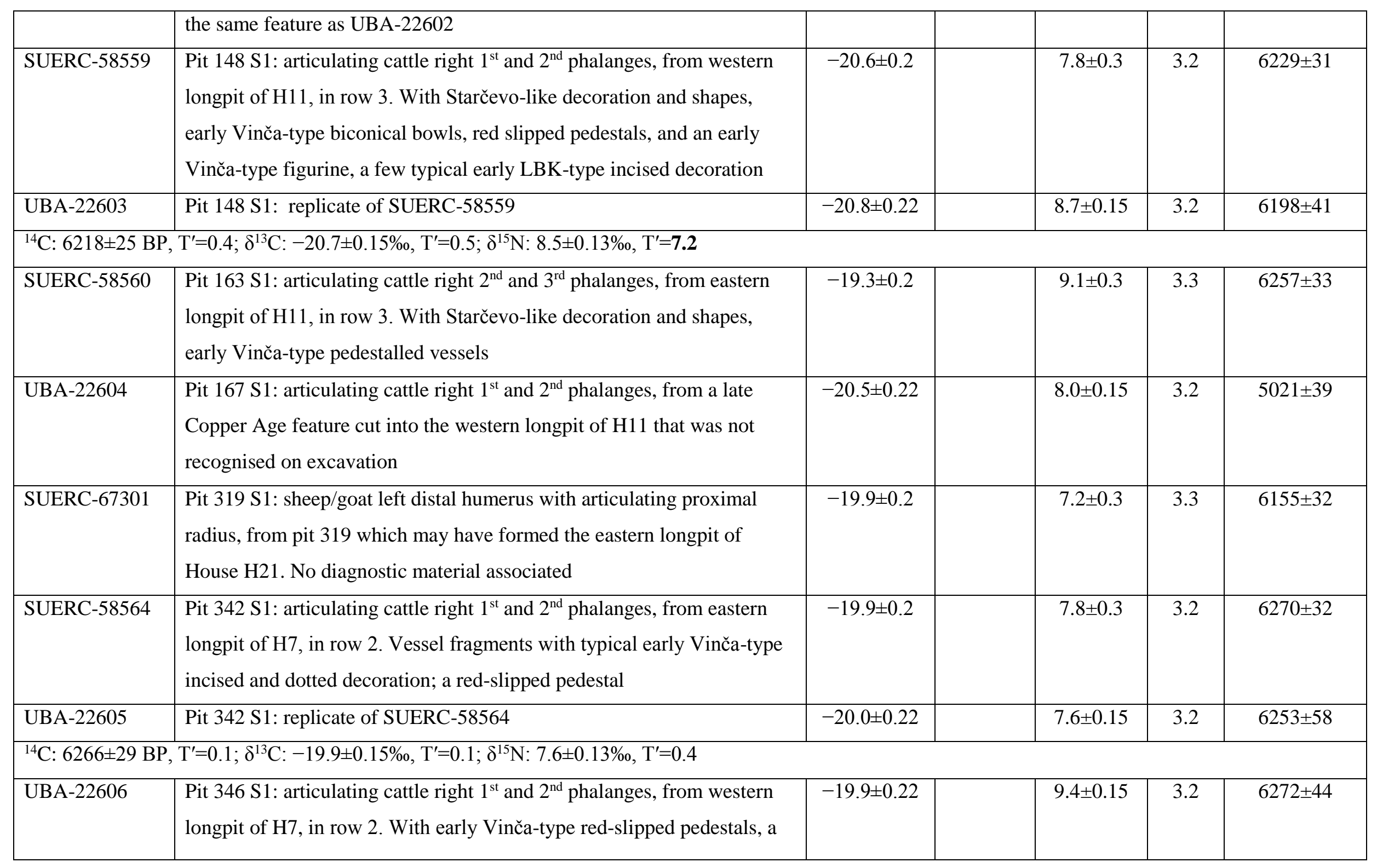




\begin{tabular}{|c|c|c|c|c|c|}
\hline & few typical early LBK-type incised decoration & & & & \\
\hline SUERC-67286 & $\begin{array}{l}\text { Pit } 345 \text { S1: articulating cattle right } 2^{\text {nd }} \text { and } 3^{\text {rd }} \text { phalanges, from the shared } \\
\text { longpit of Houses } H 12 \text { and H13. With early LBK-type incised } \\
\text { decoration }\end{array}$ & $-19.5 \pm 0.2$ & $9.3 \pm 0.3$ & 3.4 & $6163 \pm 30$ \\
\hline UBA-22607 & $\begin{array}{l}\text { Pit } 362 \text { S1: articulating cattle left distal tibia unfused epiphysis and } \\
\text { proximal astragalus, from eastern longpit of H12, in row 3. Early Vinča- } \\
\text { type figurine, biconical bowl and red slipped pedestalled vessels, vessel } \\
\text { fragments with early LBK-like incised decoration and goat protome } \\
\text { Starčevo-like low pedestal and barbotine decoration }\end{array}$ & $-19.0 \pm 0.22$ & $8.2 \pm 0.15$ & 3.2 & $6251 \pm 43$ \\
\hline SUERC-58565 & $\begin{array}{l}\text { Pit } 362 \text { S3: articulating cattle right } 2^{\text {nd }} \text { and } 3^{\text {rd }} \text { phalanges, from same } \\
\text { feature as UBA- } 22607\end{array}$ & $-19.5 \pm 0.2$ & $8.8 \pm 0.3$ & 3.3 & $6168 \pm 32$ \\
\hline UBA-22609 & Pit 395 S1: replicate of SUERC-58566 & $-20.4 \pm 0.22$ & $6.9 \pm 0.15$ & 3.2 & $6348 \pm 45$ \\
\hline \multicolumn{6}{|c|}{${ }^{14} \mathrm{C}: 6285 \pm 27 \mathrm{BP}, \mathrm{T}^{\prime}=3.1 ; \delta^{13} \mathrm{C}:-20.3 \pm 0.15 \%$ o, $\mathrm{T}^{\prime}=0.5 ; \delta^{15} \mathrm{~N}: 6.9 \pm 0.13 \%$, $\mathrm{T}^{\prime}=0.1$} \\
\hline SUERC-67287 & $\begin{array}{l}\text { Pit } 396 \text { S1: articulating cattle atlas and axis, from a rounded pit, } \\
\text { associated with House H18, dug next to the western wall of the house, } \\
\text { and probably belonging to the longpit flanking the house. is With early } \\
\text { Vinča-type vessel forms and an altar fragment }\end{array}$ & $-20.7 \pm 0.2$ & $8.3 \pm 0.3$ & 3.4 & $6233 \pm 30$ \\
\hline SUERC-67288 & $\begin{array}{l}\text { Pit } 396 \text { S2: articulating cattle left } 1^{\text {st }} \text { and } 2^{\text {nd }} \text { phalanges, from the same } \\
\text { feature as SUERC- } 67287\end{array}$ & $-20.0 \pm 0.2$ & $6.9 \pm 0.3$ & 3.3 & $6227 \pm 30$ \\
\hline
\end{tabular}




\begin{tabular}{|c|c|c|c|c|c|c|}
\hline SUERC-58567 & $\begin{array}{l}\text { Pit } 414 \text { S1: articulating cattle right } 1^{\text {st }} \text { and } 2^{\text {nd }} \text { phalanges, from eastern } \\
\text { longpit of H18, in row } 4 \text {. Mainly early Vinča-type pottery and altar } \\
\text { fragment; a few typical early LBK-like incised sherds }\end{array}$ & $-20.6 \pm 0.2$ & & $7.8 \pm 0.3$ & 3.3 & $6211 \pm 32$ \\
\hline UBA-22610 & $\begin{array}{l}\text { Pit } 414 \text { S2: articulating cattle left } 1^{\text {st }} \text { and } 2^{\text {nd }} \text { phalanges, from the same } \\
\text { feature as SUERC-58567 }\end{array}$ & $-20.7 \pm 0.22$ & & $8.1 \pm 0.15$ & 3.2 & $6141 \pm 43$ \\
\hline MAMS-14830 & $\begin{array}{l}\text { Grave 415: rib from adult female human skeleton, uncovered from a } \\
\text { layer below Pit 414, which is the eastern longpit of H18, in row } 4\end{array}$ & & -14.7 & & 3.2 & $6321 \pm 28$ \\
\hline SUERC-58568 & $\begin{array}{l}\text { Pit } 420 \mathrm{~S} 1 \text { : articulating cattle right } 1^{\text {st }} \text { and } 2^{\text {nd }} \text { phalanges, from western } \\
\text { longpit of } \mathrm{H} 17 \text {, in row } 4 \text {. Mainly early Vinča-type pottery and bone } \\
\text { spoon, a few early LBK type incised pottery fragment }\end{array}$ & $-19.9 \pm 0.2$ & & $7.7 \pm 0.3$ & 3.3 & $6235 \pm 31$ \\
\hline UBA-22611 & Pit 420 S1: replicate of SUERC-58568 & $-20.2 \pm 0.22$ & & $8.0 \pm 0.15$ & 3.2 & $6201 \pm 49$ \\
\hline \multicolumn{7}{|c|}{${ }^{14} \mathrm{C}: 6225 \pm 27 \mathrm{BP}, \mathrm{T}^{\prime}=0.3 ; \delta^{13} \mathrm{C}:-20.0 \pm 0.15 \%$, $\mathrm{T}^{\prime}=1.0 ; \delta^{15} \mathrm{~N}: 7.9 \pm 0.13 \%, \mathrm{~T}^{\prime}=0.8$} \\
\hline SUERC-67289 & $\begin{array}{l}\text { Pit } 434 \text { S1: articulating cattle right } 2^{\text {nd }} \text { and } 3^{\text {rd }} \text { phalanges, from western } \\
\text { long-pit of H20. No diagnostic material associated }\end{array}$ & $-20.4 \pm 0.2$ & & $8.6 \pm 0.3$ & 3.3 & $6220 \pm 30$ \\
\hline SUERC-58569 & $\begin{array}{l}\text { Pit } 443 \text { S1: articulating sheep/goat thoracic vertebrae, from southern part } \\
\text { of the western longpit of H15, in row } 3 \text {. With very typical early Vinča- } \\
\text { type biconical bowls, red slipped pedestalled vessels and fragments of a } \\
\text { figurine }\end{array}$ & $-20.5 \pm 0.2$ & & $8.0 \pm 0.3$ & 3.2 & $6247 \pm 33$ \\
\hline UBA-22612 & $\begin{array}{l}\text { Pit } 451 \text { S1: articulating sheep/goat right proximal radius and ulna, from } \\
\text { western longpit of H6, in the eastern part of row 3. Fragments of early } \\
\text { Vinča-type (Vinča A) conical bowls and red-slipped pedestal; early } \\
\text { LBK-style (and some Alföld LBK) vessels }\end{array}$ & $-20.2 \pm 0.22$ & & $6.8 \pm 0.15$ & 3.2 & $6165 \pm 40$ \\
\hline
\end{tabular}




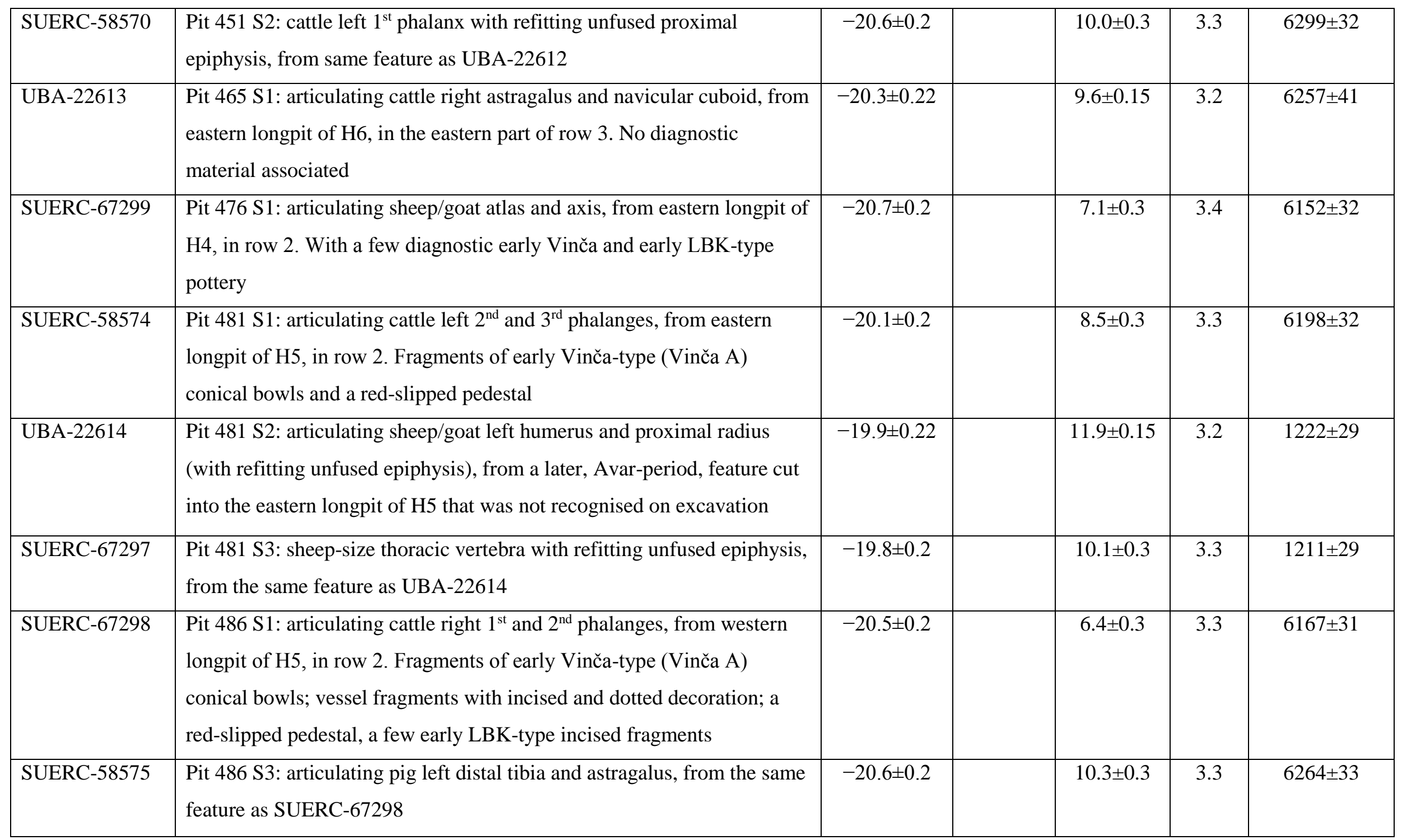




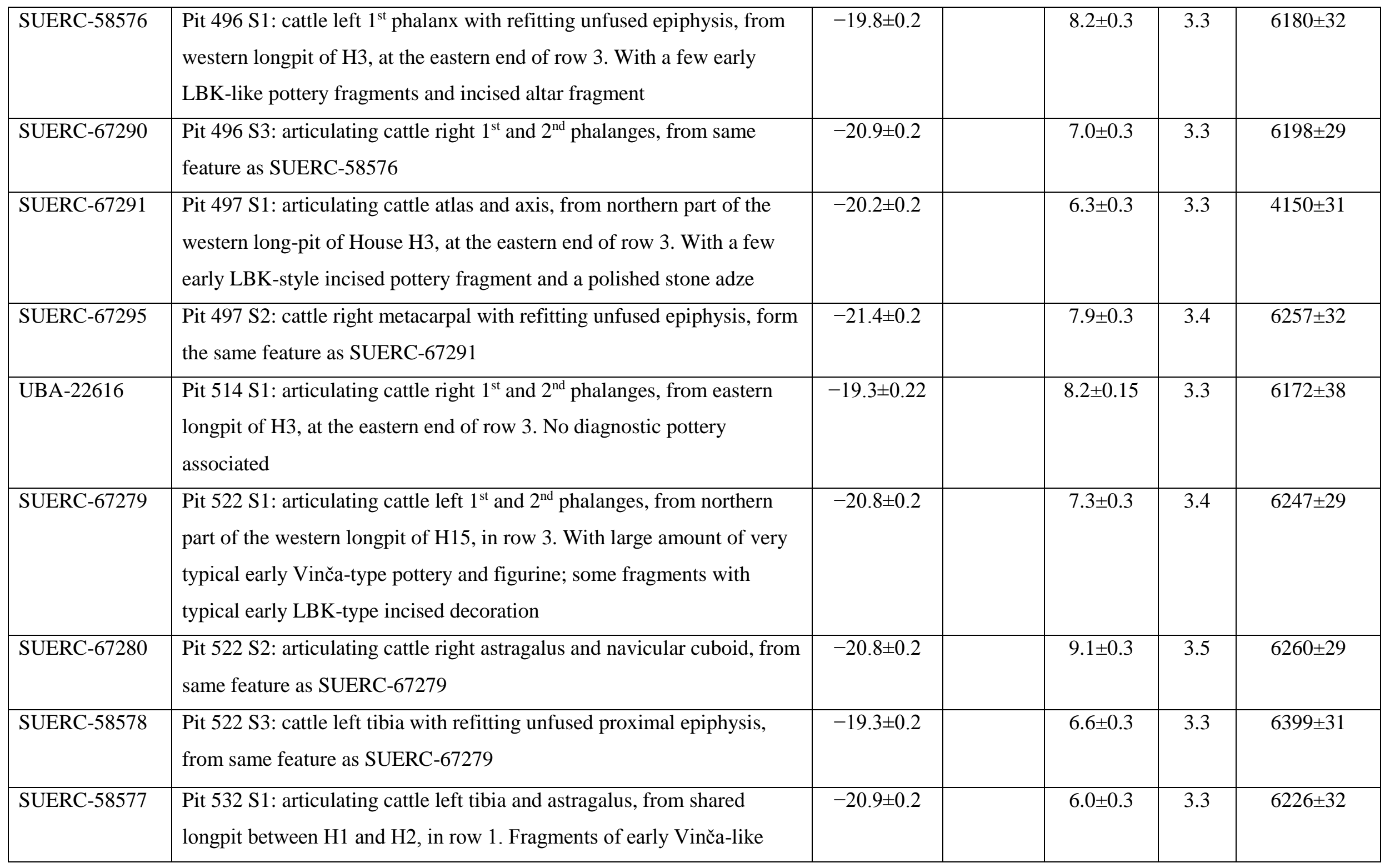




\begin{tabular}{|c|c|c|c|c|c|}
\hline & biconical bowls and pedestalled vessels, fragments of an incised altar & & & & \\
\hline UBA-22617 & $\begin{array}{l}\text { Pit } 532 \text { S2; cattle left metacarpal with refitting unfused distal epiphysis, } \\
\text { from same feature as SUERC- } 58577\end{array}$ & $-18.1 \pm 0.22$ & $7.7 \pm 0.15$ & 3.2 & $6198 \pm 39$ \\
\hline \multicolumn{6}{|l|}{ Western } \\
\hline SUERC-58550 & $\begin{array}{l}\text { Pit } 1048 \text { S1: articulating cattle left humerus and radius, from pit } 1048 . \\
\text { Contained some typical early Sopot/Ražište-type pottery and some } \\
\text { LBK-like (Malo Korenovo-style) pottery }\end{array}$ & $-20.3 \pm 0.2$ & $9.6 \pm 0.3$ & 3.3 & $6266 \pm 31$ \\
\hline UBA-22598 & $\begin{array}{l}\text { Pit } 1048 \text { S3: articulating cattle left tibia and astragalus, from same } \\
\text { feature as SUERC-58550 }\end{array}$ & $-20.1 \pm 0.22$ & $9.2 \pm 0.15$ & 3.2 & $6166 \pm 50$ \\
\hline SUERC-67305 & $\begin{array}{l}\text { Grave } 1049 \text { S1: rib from mature adult male crouched skeleton lying on } \\
\text { its left side, which cuts pit-complex } 1073 .\end{array}$ & $-19.9 \pm 0.2$ & $10.4 \pm 0.3$ & 3.2 & $6059 \pm 29$ \\
\hline SUERC-67306 & $\begin{array}{l}\text { Grave } 1078 \text { S1: rib from adult male crouched skeleton lying on its right } \\
\text { side, which cuts pit complex } 1113 \text {. Pit } 1113 \text { contained some typical } \\
\text { Vinča-style red-slipped pedestal vessels. }\end{array}$ & $-19.5 \pm 0.2$ & $9.7 \pm 0.3$ & 3.3 & $6047 \pm 29$ \\
\hline
\end{tabular}




\begin{tabular}{|c|c|c|c|c|c|c|}
\hline SUERC-67307 & $\begin{array}{l}\text { Grave } 1121 \text { S1: clavicle from sub-adult crouched skeleton lying on its } \\
\text { right side, which cuts pit complex } 1123 \text {. Pit } 1123 \text { contained large } \\
\text { amount of very typical early Sopot/Ražište-type. }\end{array}$ & $-19.5 \pm 0.2$ & & $9.7 \pm 0.3$ & 3.3 & $6125 \pm 29$ \\
\hline UBA-22596 & $\begin{array}{l}\text { Grave } 1124 \text { S1: right femur from adult female crouched skeleton lying } \\
\text { on its right side, which cuts the pit complex } 1123 \text {. Pit } 1123 \text { contained } \\
\text { large amount of very typical early Sopot/Ražište-type pottery }\end{array}$ & $-20.3 \pm 0.22$ & & $9.8 \pm 0.15$ & 3.3 & $6252 \pm 41$ \\
\hline SUERC-58555 & $\begin{array}{l}\text { Pit } 1387 \text { S1: articulating cattle right } 1^{\text {st }} \text { and } 2^{\text {nd }} \text { phalanges, from pit } 1387 . \\
\text { Contained a large amount of very typical early Sopot/Ražište-type } \\
\text { pottery and some LBK-like incised (Malo Korenovo-style) pottery } \\
\text { fragment. }\end{array}$ & $-20.0 \pm 0.2$ & & $9.1 \pm 0.3$ & 3.3 & $6199 \pm 32$ \\
\hline UBA-22600 & $\begin{array}{l}\text { Pit } 1387 \text { S2: articulating cattle left } 1^{\text {st }} \text { and } 2^{\text {nd }} \text { phalanges, from same } \\
\text { feature as SUERC- } 58555\end{array}$ & $-18.7 \pm 0.22$ & & $9.4 \pm 0.15$ & 3.2 & $6221 \pm 40$ \\
\hline MAMS-14832 & $\begin{array}{l}\text { Grave 1394: tibia from mature adult female crouched skeleton lying on } \\
\text { its left side, which cuts pit 1387, which contained a large amount of very } \\
\text { typical early Sopot/Ražište-type pottery and some LBK-like incised } \\
\text { (Malo Korenovo-style) pottery fragment. }\end{array}$ & & -23.4 & & 3.3 & $6226 \pm 30$ \\
\hline UBA-22597 & $\begin{array}{l}\text { Grave } 1561 \text { S1: left femur from adult female crouched skeleton lying on } \\
\text { its left side which cuts pit-complex 1570, located in the western part of }\end{array}$ & $-20.5 \pm 0.22$ & & $10.2 \pm 0.15$ & 3.3 & $6180 \pm 51$ \\
\hline
\end{tabular}




\begin{tabular}{|c|c|c|c|c|c|c|}
\hline & the excavated area. & & & & & \\
\hline SUERC-67308 & $\begin{array}{l}\text { Grave } 1720 \text { S1: scapula from sub-adult crouched skeleton, which cuts } \\
\text { pit } 1287 .\end{array}$ & $-19.9 \pm 0.2$ & & $10.5 \pm 0.3$ & 3.2 & $6166 \pm 29$ \\
\hline SUERC-67310 & $\begin{array}{l}\text { Grave } 1995 \text { S1: rib from adult female crouched skeleton lying on its left } \\
\text { side which cuts pit 1767, located in the western part of the excavated } \\
\text { area. It contained a large amount of typical early Sopot/Ražište-type and } \\
\text { some LBK-like (Malo Korenovo-style) pottery }\end{array}$ & $-19.9 \pm 0.2$ & & $9.6 \pm 0.3$ & 3.3 & $6140 \pm 29$ \\
\hline MAMS-14833 & $\begin{array}{l}\text { Grave 2030: cranium from adult female crouched skeleton lying on its } \\
\text { left side, dug into pit } 2034 \text {, which contained some typical early } \\
\text { Sopot/Ražište-type pottery }\end{array}$ & & -19.3 & & 3.3 & $6186 \pm 29$ \\
\hline
\end{tabular}


Table 2. Highest Posterior Density intervals for key parameters from Versend-Gilencsa, derived from Model 4 (Figures 4-5).

\begin{tabular}{|c|c|c|}
\hline Parameter & $\begin{array}{l}\text { Highest Posterior } \\
\text { Density interval (95\% } \\
\text { probability) }\end{array}$ & $\begin{array}{l}\text { Highest Posterior } \\
\text { Density interval (68\% } \\
\text { probability) }\end{array}$ \\
\hline start Versend burials & $5395-5225 \mathrm{cal} \mathrm{BC}$ & $5330-5240$ cal BC \\
\hline end Versend burials & $5040-4815 \mathrm{cal} \mathrm{BC}$ & 4995-4905 cal BC \\
\hline use Versend burials & $215-540$ years & 275-415 years \\
\hline $\begin{array}{l}\text { start Versend } \\
\text { settlement }\end{array}$ & $\begin{array}{c}5305-5280 \mathrm{cal} \mathrm{BC} \\
(2 \%) \text { or } 5255-5210 \mathrm{cal} \\
B C(93 \%)\end{array}$ & $5235-5215 \mathrm{cal} \mathrm{BC}$ \\
\hline end Versend settlement & $\begin{array}{c}5220-5180 \text { cal BC } \\
(93 \%) \text { or } 5150-5115 \\
\text { cal BC }(2 \%)\end{array}$ & $5210-5195 \mathrm{cal} \mathrm{BC}$ \\
\hline use Versend settlement & $\begin{array}{l}1-70 \text { years }(93 \%) \text { or } \\
135-185 \text { years }(2 \%)\end{array}$ & 10-35 years \\
\hline first $H 1$ or $H 2$ & $5245-5200 \mathrm{cal} \mathrm{BC}$ & $5225-5210 \mathrm{cal} \mathrm{BC}$ \\
\hline last $H 1$ or $H 2$ & $5230-5185 \mathrm{cal} \mathrm{BC}$ & $5215-5200 \mathrm{cal} \mathrm{BC}$ \\
\hline use $H 1$ or $H 2$ & 1-40 years & $1-15$ years \\
\hline first $H 3$ & $5250-5205 \mathrm{cal} \mathrm{BC}$ & $5230-5215 \mathrm{cal} \mathrm{BC}$ \\
\hline last H3 & $\begin{array}{c}5220-5185 \mathrm{cal} \mathrm{BC} \\
(94 \%) \text { or } \\
5170-5140 \mathrm{cal} \mathrm{BC} \\
(1 \%)\end{array}$ & $5215-5200 \mathrm{cal} \mathrm{BC}$ \\
\hline use H3 & $\begin{array}{l}1-60 \text { years }(94 \%) \text { or } \\
75-100 \text { years }(1 \%)\end{array}$ & $1-25$ years \\
\hline first H5 & $5250-5205 \mathrm{cal} \mathrm{BC}$ & $5230-5210 \mathrm{cal} \mathrm{BC}$ \\
\hline last H5 & $\begin{array}{c}5225-5185 \mathrm{cal} \mathrm{BC} \\
(94 \%) \text { or } \\
5175-5155 \mathrm{cal} \mathrm{BC} \\
(1 \%)\end{array}$ & $5215-5200 \mathrm{cal} \mathrm{BC}$ \\
\hline
\end{tabular}




\begin{tabular}{|c|c|c|}
\hline use H5 & $1-65$ years & $1-20$ years \\
\hline first H6 & $5255-5210 \mathrm{cal} \mathrm{BC}$ & $5230-5215 \mathrm{cal} \mathrm{BC}$ \\
\hline last H6 & $5230-5180 \mathrm{cal} \mathrm{BC}$ & $5220-5200 \mathrm{cal} \mathrm{BC}$ \\
\hline use H6 & $1-70$ years & $1-25$ years \\
\hline first $H 7$ & $5255-5205 \mathrm{cal} \mathrm{BC}$ & $5230-5215 \mathrm{cal} \mathrm{BC}$ \\
\hline last H7 & $5240-5200 \mathrm{cal} \mathrm{BC}$ & $5225-5210 \mathrm{cal} \mathrm{BC}$ \\
\hline use H7 & $1-25$ years & $1-10$ years \\
\hline first H9 & $5250-5205 \mathrm{cal} \mathrm{BC}$ & $5230-5215 \mathrm{cal} \mathrm{BC}$ \\
\hline last H9 & $5220-5170 \mathrm{cal} \mathrm{BC}$ & $5215-5200 \mathrm{cal} \mathrm{BC}$ \\
\hline use H9 & $1-80$ years & $5-25$ years \\
\hline first $\mathrm{H} 10$ & $5260-5210 \mathrm{cal} \mathrm{BC}$ & $5230-5215 \mathrm{cal} \mathrm{BC}$ \\
\hline last $\mathrm{H} 10$ & $5230-5185 \mathrm{cal} \mathrm{BC}$ & $5220-5200 \mathrm{cal} \mathrm{BC}$ \\
\hline use HIO & $1-70$ years & $1-20$ years \\
\hline first $H 11$ & $5250-5205 \mathrm{cal} \mathrm{BC}$ & $5230-5210 \mathrm{cal} \mathrm{BC}$ \\
\hline last H11 & $5235-5195 \mathrm{cal} \mathrm{BC}$ & $5220-5205 \mathrm{cal} \mathrm{BC}$ \\
\hline use H11 & $1-35$ years & $1-15$ years \\
\hline first $H 12$ & $5245-5200 \mathrm{cal} \mathrm{BC}$ & $5225-5210 \mathrm{cal} \mathrm{BC}$ \\
\hline last H12 & $5230-5170 \mathrm{cal} \mathrm{BC}$ & $5215-5200 \mathrm{cal} \mathrm{BC}$ \\
\hline use H12 & $1-50$ years & $1-15$ years \\
\hline \multirow[t]{4}{*}{ first $H 15$} & $5285-5265 \mathrm{cal} \mathrm{BC}$ & $5235-5215 \mathrm{cal} \mathrm{BC}$ \\
\hline & $(2 \%)$ or & \\
\hline & $5255-5210 \mathrm{cal} \mathrm{BC}$ & \\
\hline & $(93 \%)$ & \\
\hline last H15 & $5230-5195 \mathrm{cal} \mathrm{BC}$ & $5220-5205 \mathrm{cal} \mathrm{BC}$ \\
\hline use H15 & $1-60$ years & $1-20$ years \\
\hline first $H 18$ & $5245-5205 \mathrm{cal} \mathrm{BC}$ & $5225-5210 \mathrm{cal} \mathrm{BC}$ \\
\hline \multirow[t]{3}{*}{ last $H 18$} & $5220-5185 \mathrm{cal} \mathrm{BC}$ & $5215-5200 \mathrm{cal} \mathrm{BC}$ \\
\hline & $(94 \%)$ or $5165-5135$ & \\
\hline & cal BC $(1 \%)$ & \\
\hline use H18 & $1-70$ years & $1-20$ years \\
\hline
\end{tabular}

